\title{
CIRCULAR ECONOMY CONCEPTS APPLIED TO WASTE ANAEROBIC DIGESTION PLANTS
}

\author{
FRANCESCO PALERMITO ${ }^{1}$, ELENA MAGARIL ${ }^{2}$, FABIO CONTI ${ }^{3}$, \\ ANDREY KISELEV ${ }^{2} \&$ ELENA C. RADA ${ }^{3}$ \\ ${ }^{1}$ Department of Civil, Environmental and Mechanical Engineering, University of Trento, Italy \\ ${ }^{2}$ Department of Environmental Economics, Ural Federal University, Russia \\ ${ }^{3}$ Department of Theoretical and Applied Sciences, University of Insubria, Italy
}

\begin{abstract}
Anaerobic digestion contributes to the implementation of circular economy (CE) concepts. This process is assuming an increasingly important function in the treatment of the organic fraction of municipal solid waste (MSW), that is, food waste, where selective collection is optimised. The possibility of combining the recovery of matter with energy makes this approach interesting for the concepts of circular economy. Specifically, the extraction of biomethane from biogas and the following refining of the residual off-gas from impurities gives as result the extraction of $\mathrm{CO}_{2}$ that can also be used for food industry applications. A high-quality source separation of food waste gives the chance to generate a good product, compost, coherently with the aims of the circular economy principles. The use of dry processes of anaerobic digestion allows avoiding the discharge of (treated) water in the environment. Co-digestion is another option that deserves a wider adoption, because of the possibility to exploit existing volumes of digestion. This paper presents a bibliographic research based on current $\mathrm{CE}$ progress and MSW anaerobic digestion infrastructure in Italy and Russia. Perspectives of the sector are discussed too.

Keywords: anaerobic digestion, biomethane, $\mathrm{CO}_{2}$, food industry, food waste, organic fraction of municipal solid waste.
\end{abstract}

\section{INTRODUCTION}

Circular economy (CE) is one of the most studied and developed topics in the last decade. The CE concept is based on the intelligent use of the resources with minimum residues generation. The main idea is the use of all the primary resources in the various stages of different processes and the reuse of their generated residues as secondary resources in other processes. In this way the environmental pollution is decreased also thanks to the less extraction and use of the primary resources and to the reduced need of final treatments for residues.

In 2014 in the EU, the first CE legislative proposal was issued. This was improved in 2015, with the release of a new package "EU action plan for the CE". Inside many proposals were added regarding the changes to be made to the Waste European Directive 2008/98/CE, 1994/62/CE, 2000/53/EC, 2000/66/EC, 2012/19/EU and to the 1999/31/EC. Different targets are requested for recycling of different municipal solid waste (MSW) fractions and the landfilling of selectively collected waste was and is prohibited.

Also details regarding the promotion of economic instruments, concrete measures to promote reuse and stimulate industrial symbiosis and economic incentives for producers are indicated. In 2018 the four directives of the "circular economy package" entered into force and the Member States had to transpose them by July 2020; new targets were requested for 2025, 2030 and 2035 for the waste management. The last release regarding CE was in March 2020: "A new action plan for the circular economy for a cleaner and more competitive Europe".

The CE applied to the management of MSW is used with advantages in the European Union (EU), thanks to real application to improve and upgrade the MSW plants. The aim is 
to optimize the entire integrated MSW cycles and/or technology in order to minimize the use of landfill.

The present work provides a bibliographic overview of technological improvements of the current anaerobic digestion (AD) plants, as well as the construction of new ones, to fit the objectives of CE issues in Italy and Russia.

\section{MATERIALS AND METHODS}

The methodological approach is based on several steps, giving first of all an overview that includes: (i) assessment of CE evolution in EU and Russia; (ii) facts and figures of MSW generation rate; (iii) Italian and Russian MSW AD plants overview; and (iv) finding ways of current/future $\mathrm{AD}$ plants improvement in order to fit $\mathrm{CE}$ principles. A following zoom on the perspectives of $\mathrm{AD}$ upgrading under a $\mathrm{CE}$ view offers the opportunity of a discussion on the prospects of this sector.

\section{OVERVIEW}

\subsection{Circular economy evolution}

The European Commission (EU) presented its first communication on the Circular Economy (CE) in July 2014, through the Communication "Towards a circular economy: a zero-waste programme for Europe" [1]. In December 2014, the European Commission decided to withdraw its legislative proposal on waste, committing at the same time to present a new package by the end of 2015. This new one, was an ambitious CE Action Plan: "European Union Action plan for the Circular Economy" [2]. This new package included the "Closing the loop - An EU action plan for the Circular Economy" and some legislative proposals regarding the changes to be made to the Waste European Directive 2008/98/CE, 1994/62/CE, 2000/53/EC, 2000/66/EC, 2012/19/EU and to the 1999/31/EC [3].

The legislative proposal on waste sets specific targets for their reduction and establishes an ambitious long-term path for waste management and recycling. In particular the proposal includes an EU target for 2030 for recycling $65 \%$ of MSW, 75\% of packaging waste and a binding landfill target to reduce landfill to maximum of $10 \%$ of MSW. Moreover the package includes a ban on landfilling of selectively collected waste, the promotion of economic instruments in order to discourage landfilling, simplified definitions and harmonised calculation methods for recycling rates throughout the EU, concrete measures to promote reuse and stimulate industrial symbiosis turning one industry's by-product into another industry's raw material, economic incentives for producers to put greener products on the market and support recovery and recycling schemes [4].

In 2018 the four directives of the "circular economy package" entered into force and the Member States had to transpose them by July 2020 . New targets were requested: MSW recycling: $55 \%$ by 2025 ( $60 \%$ by 2030 and $65 \%$ by 2035), packaging waste recycling: $65 \%$ of packaging waste by 2025 (70\% by 2030) and it was maintained the indications for residual municipal solid waste (RMSW) landfilling to a maximum of $10 \%$ by 2035 .

In March 2020, the last CE Action Plan was adopted "A new action plan for the circular economy for a cleaner and more competitive Europe". This new Action Plan considers the entire life cycle of products (LCP) in order to use the resources in an EU economy as long as possible [5]. The sustainability, green and the environmentally friendly processes and use are also indicated to be considered during the LCP.

In the last 6 years, papers on MSW policy/management and Circular Economy where published reporting data regarding all the MSW life: from production, collection, use and 
reuse, treatments and final disposal in EU [6]-[15]; some papers ranked the European countries considering the CE performances [16], [17].

In Italy, the legislative process concerning the CE started in 2016 with the issue of the "Collegato Ambientale", containing provisions on environmental legislation to promote the green economy and sustainable development [18]. In 2018 more than 50\% of the MSW was recycled and only $22 \%$ was landfilled in Italy [19]. The Italian CE approach to MSW was studied and some papers were published [20]-[23]. However, Italy has not yet adopted a national strategy and an action plan for the circular economy; only the framework and strategic positioning document "Towards a circular economy model for Italy" was issued in 2017 [24]. Italy, in 2019, also transposed 33 European directives (2018-2019) through the law 117 "Delega al Governo per il recepimento delle direttive europee" of 4 October 2019 [25]. However, Italy in the Circular Economy Report of ENEA is ranked as first EU country thanks to its capacity to efficient use of the resources considering the production, consumption, waste management, secondary raw materials market, investments and employment [26].

Russia is one of the non-EU countries that considered it is important to implement different strategies in order to become a country where the Circular Economy and green concepts could be fully adopted, not only for the MSW management but also for other sectors: energy, economy and business models [27]-[33]. Since 2017 the new national waste management strategy, including waste reform and environmental taxes, was introduced, starting from the Federal Law No. 89-FZ "On Production and Consumption of Wastes" and Federal Law No. 7-FZ “On Environmental Protection" [34]-[36]. In 2017, in order to reduce the amount of landfilled MSW, a list of 182 recyclable waste materials that are prohibited to be taken to landfills was approved. In 2018, the new strategy for waste treatment and utilization industry development until 2030 was adopted. These documents are primarily focused on the policies of developed countries, including EU members, the USA and Japan. The Russian target for 2030 is to recycle $80 \%$ of MSW [37], [38].

\subsection{Municipal solid waste (MSW) and organic fraction of MSW (OFMSW)}

In 2018, in the EU countries, the MSW generation varies considerably, ranging from $272 \mathrm{~kg}$ per capita in Romania to $814 \mathrm{~kg}$ per capita in Denmark. This variation depends on many factors but the most important are economic power and consumption habits [39].

The MSW generated in EU countries is managed in different ways, depending on the existing MSW treatment plants in each country, through combustion, aerobic and anaerobic treatment and also landfilling. From the Eurostat data it is clear that each EU country tried to avoid landfilling as much as possible: MSW increased compared with other years but its landfilled percentage decreased: from $61 \%$ in 1995 to $24 \%$ in 2018 [39]. This reduction can partly be attributed to the implementation of European legislation.

In Italy, in 2018, the MSW production was about 30 million tons (499 $\mathrm{kg}$ per capita, in line with the European average) and $58 \%$ of this being collected separately [40]. The implementation of the MSW selective collection and the introduction of a tariff had an important effect of the MSW production in Italy [12], [41]-[44].

In 2018, $646 \mathrm{MSW}$ treatment plants were operational in order to manage all the produced municipal solid waste. Among them, 339 of these were dedicated to the treatment of the MSW organic fractions (OFMSW): 281 composting plants, 35 plants for integrated aerobic/ anaerobic treatment and 23 anaerobic digestion (AD) plants. Moreover, 131 were plants for intermediate mechanical or mechanical biological treatment of waste, in addition to 38 
incineration plants and 11 industrial plants that co-incinerate MSW. Apart these, also 127 landfills were operated in order to assure the final disposal of the residues [40].

OFMSW is a mix of many sub-fractions: food and kitchen waste generated from households, restaurants, caterers, retail premises, comparable waste from food processing plants, representing $60 \%$ of the overall municipal bio-waste produced in the EU-28; garden waste is around $35 \%$; the remaining $5 \%$ is classified as "other" [45]. The most adopted treatments for OFMSW in Europe are composting and anaerobic digestion (alone and/or with other biodegradable materials) [46]-[51]. In the last years also, new ways to treat and use the OFMSW were studied in order to comply more with the CE concepts: bio-hydrogen generation and hydro-bio-chair production [52]-[55].

In Italy, the OFMSW has the following codes: EER 200108 (kitchens and canteens), EER 200201 (gardens and parks) and EER 200302 (markets); about 6.7 million tons were collected in 2018 [56]. About half of this selectively collected quantity, is sent to composting, about $44 \%$ in integrated aerobic/anaerobic plants and the rest in other AD plants [56].

In Russia, in 2018, the MSW production was 53.9 million tons (367 kg per capita) and more than $90 \%$ is landfilled [37]. The MSW collection is carried out in a substantially mixed way: waste without pre-sorting is collected in containers. Mixed MSW collection leads towards the increased loads on polygons with the inability to extract recyclable materials. This issue together with the dramatic waste accumulation is the problem that needs to be urgently addressed. Additional factors inhibiting the development of circular economy concept include:

- Low engagement rate of recycled materials and by-products into industrial circulation.

- Technological decay of existing waste processing factories: nowadays the vast majority of waste separation factories in Russia sort components through manual labour; in some cases, magnetic separation and optical methods are used.

- Shortage of effective economic and investment incentives for sectoral technological development.

- High technological dependence on imported processing technologies together with the existing sanctions restrictions [38].

An experimental research on "Mechanized processing of household waste" was developed in the last year in order to create a database useful for future waste management [57]-[60].

\subsection{Anaerobic digestion (AD) plants}

Anaerobic digestion (AD) in reactor is a biological stabilization process performed in controlled closed volumes (digesters), through which, in absence of free oxygen, the organic substance is transformed into biogas composed mainly of methane and carbon dioxide.

In Italy, the AD process of OFMSW can be found in tens of plants that show a growing interest from wet processes to dry processes. Wet processes are characterised by a moisture in the reactor that is higher than $90 \%$. Dry processes are based on moisture lower than $80 \%$. In this second case, the management of the plant can be made without liquid discharges and the reactor is more compact. A few millions of tons of OFMSW are presently treated in Italy by these approaches. The overall conventional configuration of the plants has been, until recently, a pre-treatment to divert impurities followed by the anaerobic digester, followed by an aerobic stabilisation aimed to compost production (thanks to post-treatment of refining). The aerobic stabilisation is named post-composting and is supported by the introduction of bulky agent, suitable for helping the aeration of the mass; most of this bulky agent is green waste from selective collection. In the schemes where wet digestion is performed, a 
dewatering stage is placed after anaerobic digestion and before post-composting, in order to optimise the aeration stage (excessive moisture is not compatible with a good aeration). In all the regions, where selective collection is performed well, the quality of the obtained compost is good and it can be sold easily. However, the main income for the companies of this sector depends on the tariff of treatment (e.g. $90 € / t_{\mathrm{OFMSW}}$ ) and on the electricity sold (that is supported by public incentives as the source is discarded biomass, thus renewable).

$\mathrm{AD}$ is assuming an increasingly important function in the treatment of OFMSW, thanks to the possibility of combining the recovery of matter with energy. In fact, in addition to the production of digestate to be used in the agricultural field, this type of management involves the formation of biogas which can be used directly for energy purposes for the cogeneration of electrical and thermal energy. Thermal energy is often used for internal consumption.

In 2018, the overall biogas produced by integrated anaerobic/aerobic treatment plants amounted to over 229 million $\mathrm{Nm}^{3}$. In the latest generation plants (they are five in Italy in 2018), biogas is subjected to a process of $\mathrm{CO}_{2}$ removal, called upgrading, which allows the production of biomethane and its subsequent use instead of natural gas.

Concerning Russia, several projects with landfill gas generation from MSW were implemented during last decade. The Moscow district is one of the leaders in landfill gas generation and utilization. "Torbeevo" landfill, which is located in Lyubertsy area, is a pioneer renewable energy investment project. In 2018-2020 the construction of eight regional projects with combined heat and power (CHP) units started. The total energy output will be more than 100 million $\mathrm{kWh}$ per year [61]. As mentioned above, Russia is mainly focused on landfill gas collection and generation at CHP-units. The development of AD in closed reactors in Russia is inhibited by the absence of separate garbage collection.

\subsection{CE conformity for AD plants}

The key idea of AD plants improvement is concerned about two basic CE issues:

- $\mathrm{AD}$ process intensification in order to increase biogas yield. There is a great variety of different solutions, but we are focused on techniques of mixing MSW with alternative substrates within this article. Other methods of $\mathrm{AD}$ process intensification, e.g. high thermal or pressure pretreatment of substrate or enzymes usage, lead towards energy consumption increase, including both primary energy resources and resources spent on production. Detailed cradle-to-grave economic assessment is required for evaluation. Furthermore, different substrate mixes usage usually does not require technological reequipment of $\mathrm{AD}$ plants and basic objectives of $\mathrm{CE}$ can be easily achieved.

- Extraction of additional resources from biogas. Biogas is a mixture of mainly methane $\left(\mathrm{CH}_{4}\right)$ and carbon dioxide $\left(\mathrm{CO}_{2}\right)$, containing impurities, such as $\mathrm{NH}_{3}, \mathrm{H}_{2} \mathrm{~S}$, water vapour and siloxanes [62]. 100\% and even more product use leads towards a more "circular" AD process.

\section{PERSPECTIVES FOR ANAEROBIC DIGESTION PLANTS UPGRADING UNDER A CIRCULAR ECONOMY VIEW}

This section discusses some solutions for the implementation of the CE concepts in an AD Plant. The starting point was the scientific literature regarding two solutions that could be applied to AD plants:

- increase of the biogas production thanks to the co-digestion of OFMSW with other substrates;

- $\quad$ production of biomethane and simultaneous recovery of $\mathrm{CO}_{2}$ for industrial use. 


\subsection{Increase of the biogas production thanks to the co-digestion with other substrates}

The main advantage of the AD process in reactors consists in the production of biogas with a consequent decrease of biodegradable waste landfilling and greenhouse gas emissions. A disadvantage of single substrate anaerobic digestion (mono-digestion) is connected with the possibility that in the composition of OFMSW, a percentage of improper materials and/or heavy metals may be found that inhibit microbial activity during anaerobic degradation and increases costs of pre- and post-treatments. That depends strongly on the organisation of selective collection (that seems to be compulsory for a high-quality source separated OFMSW) and on the behaviour of the users.

The anaerobic co-digestion (AcoD) is a solution proposed in real scale in order to manage the problems indicated above and to be in concordance with the CE concepts and can be used for small and large communities [63]-[65]. AcoD consists of a mixture of two or more biodegradable substrates as raw and conventional biomasses, wastewater sludge, manure, agricultural waste, etc. The advantages of the AcoD are recognized at national and international level: nutrients balance, degradation rates and buffer capacity and digestate stability improvements, dilution of toxics and/or inhibitory compounds [65]-[69]. Moreover, when applied to an existing plant of mono-digestion (specifically of wet digestion), the advantage is an increased exploitation of the volume already available; however, verifications must be made to the compatibility (or upgradability) of each step of the plant; receiving, pre-treatment and feeding stages, maximum viable load, bulky agent availability for the increased post-treatment stream, final refining efficiency with the new stream; additionally, the increased biogas production must be analysed in terms of compatibility with the existing treatments and exploitation devices (e.g. an engine) and with the existing contracts for electivity selling. Another potential criticality is the regulatory frame: mixing agricultural biomasses with OFMSW can switch the authorisation pathway of the first ones to the more complex field of waste caused by OFMSW co-treatment.

Sometimes, co-digestion can be simple to perform as explained in the following case study.

Abad et al. [70] estimated the economic impact associated with biogas production increase in an anaerobic digestion plant treating source selected OFMSW, when shifting from a monodigestion to a co-digestion scenario. The selected AD plant is the Vallès Oriental Waste Treatment Centre, a public medium-scale wet AD plant (BTA ${ }^{\circledR}$ technologies) located in Granollers (Catalonia, Spain). In order to maximize the plant biogas productivity through AcoD strategies, the Vallès Oriental Waste Management Consortium is identifying opportunities to increase the production of biogas by using local substrates (produced in the surroundings of the plant) in an AcoD process along with the OFMSW. In particular, the studied co-substrates were obtained from industries located within a radius of $5 \mathrm{~km}$ from the Plant. For instance, wastes generated from 4 supermarkets were processed at full scale. Batch tests were performed in order to determine the Biochemical Methane Potential (BMP) (a measure of methane production) for each substrate and reference waste (OFMSW). As a result, it was noticed that the net biogas production of the co-substrates from supermarkets was greater than reference OFMSW. However, a criticality to be analysed is the cost of the new rejects that can be generated when adding new biomass, as pointed out in the cited case study.

Sometimes, co-digestion can be complex to perform as explained below.

To this concern, an interesting case of co-digestion is based on the addition of OFMSW to (civil) sewage sludge digester already built. From the technical point of view the verifications and consequent modifications are similar to what written above; the main 
problem is the quality of sewage sludge, mostly in terms of micro-contaminants. Often, whoever manages a sewerage authorises the discharge into the sewer of non-domestic wastewater that can worsen the quality of the generable sewage sludge, making even impossible its conversion into compost (for regulatory limits of pollutants to be complied with). Thus, the addition of well selected OFMSW to sewage sludge could change the fate of OFMSW alone (from a potential conversion into compost to an alternative that could be no longer "green"). Supposing to solve this problem with a revision of the authorisations to discharge (asking specific pre-treatments) a problem remains: a civil sewerage receives domestic discharges where one can detect the presence of pathogens that can concentrate in the sludge and reach the final product (compost). The COVID-19 pandemic is a demonstration of this phenomenon as this virus is detected in the treated wastewater and thus it can be present also in the generated sewage sludge and its derived products [71].

\subsection{Extraction of biomethane and simultaneous recovery of $\mathrm{CO}_{2}$ for industrial use}

Carbon dioxide is a greenhouse gas and its production is mostly related to the use of fossil fuels for energy production. According to the agreement proposed in Paris in 2015 with the aim to reduce greenhouse gas emissions, it is important to increase the use of renewable sources of energy promoting plans for $\mathrm{CO}_{2}$ capture and storage or utilization.

In particular the reuse of anthropogenic $\mathrm{CO}_{2}$ would reduce the necessity to extract $\mathrm{CO}_{2}$ from natural deposits promoting at the same time a circular bioeconomy of $\mathrm{CO}_{2}$. In this context, the biogas obtained by $\mathrm{AD}$ is an important source of eco-sustainable energy.

Raw biogas is a water vapour saturated mixture of $50-65 \mathrm{vol} \%$ methane, $30-40 \mathrm{vol} \% \mathrm{CO}_{2}$ and other trace elements.

Starting from OFMSW, a study presented by Esposito et al. [72] focuses on a case study on the feasibility of biogas upgrading at full industrial scale to distribution grid quality methane, and simultaneous recovery of $\mathrm{CO}_{2}$ which reaches food-grade quality thanks to a final purification. The studied digestion plant is located on the industrial site of Montello SPA (Montello, IT) and it handles up to 400,000 ton per year of biomass (OFMSW of the Lombardy in the North of Italy). The plant includes a first step of biomass pre-treatment, followed by thermophilic anaerobic digestion $\left(55^{\circ} \mathrm{C}\right)$. The produced biogas stream from the digester is first collected in the gasometer, then a series of heat exchangers cools the stream from about $50^{\circ} \mathrm{C}$ to $10^{\circ} \mathrm{C}$. Most of the water vapour condenses and heavy organic compounds are separated from the lighter gases. Raw biogas is then fed into five parallel lines where it is purified: each of them comprises water scrubbing, desulphurization, VOC removal system, compression, coal purification and membrane separation unit. The main $\mathrm{CO}_{2} / \mathrm{CH}_{4}$ separation occurs in the membrane section where the separation takes place in a set of three different modules. The $\mathrm{CO}_{2}$ from the third membrane stage still exceeds the threshold limit for foodgrade quality according to the guidelines applied by the European Industrial Gases Association and by the International Society of Beverage Technologists (EIGA/ISBT) for $\mathrm{CO}_{2}$ used in the food industry. Therefore, the $\mathrm{CO}_{2}$ stream requires a further purification. The residual impurities in the $\mathrm{CO}_{2}$ streams that come from the five membrane separation lines, are removed in the $\mathrm{CO}_{2}$ recovery unit which includes a liquefying step and cryogenic units with elements for the compression, drying and purification of the gas stream. Then $\mathrm{CO}_{2}$ cools to $30^{\circ} \mathrm{C}$ and separates from the non-condensable gases $\left(\mathrm{N}_{2}, \mathrm{O}_{2}\right.$, and $\left.\mathrm{CH}_{4}\right)$, yielding high purity $\mathrm{CO}_{2}(99.9+\%)$, a value suitable for food-grade quality. The organoleptic test demonstrated that the $\mathrm{CO}_{2}$ is odourless, tasteless and colourless.

The total energy consumption calculated for the raw biogas purification with the membrane separation unit is $0.27-0.29 \mathrm{kWh} \mathrm{Nm}^{-3}$. This value is lower than that reported for 
other biogas upgrading technologies. Moreover, considering that the average household use of methane in Italy is estimated about $1,250 \mathrm{Nm}^{3}$ per year, the Montello/Techno Project biogas upgrading plant, with its total biomethane production capacity of $3,000 \mathrm{Nm}^{3} \mathrm{~h}^{-1}$ can satisfy the energy demand of 21,000 Italian families.

This single plant is capable of providing $0.1 \%$ of the food grade $\mathrm{CO}_{2}$ worldwide demand.

\section{CONCLUSIONS}

In this work we have observed the most typical ways of $\mathrm{AD}$ plants improvement in order to fit the basic principles of CE.

The issues considered in this paper will be essential for the development of AD plants in Italy for the nearest future. Composition and properties of MSW, as well as organic matter, differ depending on the territory, so the one all-purpose substrate to be mixed with MSW does not exist. Moreover, the transportation of this substrate can be expensive. The best strategy for each specific AD plant is to explore the spatial and economic development of the nearest territories in order to create a waste supply chain for co-digestion and distribution chain for extracted resources.

Nowadays in Russia the use of biogas reactors for MSW is not applied, but there are a number of sewage sludge digestion projects and they are rapidly developing. There is an opportunity of technological breakthrough through national waste management strategy implementation with the achievement of the EU level. The stakeholders, involved in the strategy implementation, need to take into account the location of future plants with the possibility to create a cooperation chain with potential waste suppliers and consumers of extracted materials.

The extraction of $\mathrm{CO}_{2}$ from the biogas, as a step following the extraction of biomethane, could open to new scenarios of $\mathrm{CO}_{2}$ sequestration because the industrial exploitation of this product could be saturated. This option should have a future strongly related to the economic value that can be attributed (as political strategy) to the sequestration of 1 ton of $\mathrm{CO}_{2}$.

\section{ACKNOWLEDGEMENT}

This research was supported by Act 211 Government of the Russian Federation, contract № 02.A03.21.0006.

\section{REFERENCES}

[1] European Commission, Circular economy action plan: For a cleaner and more competitive Europe. https://ec.europa.eu/environment/circular-economy/pdf/circulareconomy-communication.pdf. Accessed on: 23 Oct. 2020.

[2] European Commission, Communication from the Commission to the European Parliament, the Council, the European Economic and Social Committee and the Committee of the Regions: Closing the loop - An EU action plan for the circular economy. https://eur-lex.europa.eu/resource.html?uri=cellar:8a8ef5e8-99a0-11e5b3b7-01aa75ed71a1.0012.02/DOC_1\&format=PDF. Accessed on: 23 Oct. 2020.

[3] European Commission, Communication from the Commission to the European Parliament, the Council, the European Economic and Social Committee and the Committee of the Regions: Closing the loop - An EU action plan for the circular economy. https://eur-lex.europa.eu/legal-content/EN/TXT/HTML/?uri=CELEX: 52015DC0614\&from=IT. Accessed on: 23 Oct. 2020.

[4] Eur-Lex, https://eur-lex.europa.eu/legalcontent/EN/TXT/?qid=1453384154337\&uri= CELEX:52015DC0614. Accessed on: 23 Oct. 2020. 
[5] European Commission, First circular economy action plan. https://ec.europa.eu/ environment/circular-economy/. Accessed on: 23 Oct. 2020.

[6] Hartley, K., van Santen, R. \& Kirchherr, J., Policies for transitioning towards a circular economy: Expectations from the European Union (EU). Resources, Conservation and Recycling, 155, 104634, 2020.

[7] van Ewijk, S. \& Stegemann, J.A., Recognising waste use potential to achieve a circular economy. Waste Management, 105, pp. 1-7, 2020.

[8] Rada, E.C., Special waste valorization and renewable energy generation under a circular economy: Which priorities? WIT Transactions on Ecology and the Environment, vol. 222, WIT Press: Southampton and Boston, pp. 145-157, 2019.

[9] Nilsen, H.R., The hierarchy of resource use for a sustainable circular economy. International Journal of Social Economics, 47(1), 27-40, 2019.

[10] Pires, A. \& Martinho, G., Waste hierarchy index for circular economy in waste management. Waste Management, 95, pp. 298-305, 2019.

[11] Rada, E.C., Ragazzi, M., Torretta, V., Castagna, G., Adami, L. \& Cioca, L.I., Circular economy and waste to energy. AIP Conference Proceedings, 1968, 030050, 2018.

[12] Rada, E.C., Zatelli, C., Cioca, L.I. \& Torretta, V., Selective collection quality index for municipal solid waste management. Sustainability, 10(1), 257, 2018.

[13] Malinauskaite, J., Jouhara, H., Czajczyńska, D., Stanchev, P., Katsou, E., Rostkowski, P., Thorne, R.J., Colón, J., Ponsá, S., Al-Mansour, F., Anguilano, L., Krzyżyńska, R., López, I.C., Vlasopoulos, A. \& Spencer, N., Municipal solid waste management and waste-to-energy in the context of a circular economy and energy recycling in Europe. Energy, 141, pp. 2013-2044, 2017.

[14] Rada, E.C. \& Cioca, L., Optimizing the methodology of characterization of municipal solid waste in EU under a circular economy perspective. Energy Procedia, 119, pp. 72-85, 2017.

[15] Wilts, H. \& Von Gries, N., Europe's waste incineration capacities in a circular economy. Proceedings of Institution of Civil Engineers: Waste and Resource Management, 168(4), pp. 166-176, 2015.

[16] Giannakitsidou, O., Giannikos, I. \& Chondrou, A., Ranking European countries on the basis of their environmental and circular economy performance: A DEA application in MSW. Waste Management, 109, pp. 181-191, 2020.

[17] Marino, A. \& Pariso, P., Comparing European countries' performances in the transition towards the circular economy. The Science of the Total Environment, 729, pp. 138-142, 2020.

[18] Camera dei Deputati, XVII Legislature Special Provisions. https://www.camera.it/ leg17/522?tema=collegato_ambientale Accessed on: 23 Oct. 2020.

[19] Circular Economy Network, Rapporto sull'economia circolare in Italia, Con focus sulla bioeconomia, Sintesi del rapport 2020. https://www.enea.it/it/seguici/ pubblicazioni/pdf-volumi/2020/sintesi-rapporto-sulleconomia-circolare-in-italia2020.pdf Accessed on: 23 Oct. 2020.

[20] Ghisellini, P. \& Ulgiati, S., Circular economy transition in Italy: Achievements, perspectives and constraints. Journal of Cleaner Production, 243, 118360, 2020.

[21] Savastano, M., Belcastro, M. \& Dentale, F., The role of waste collection centers in a circular economy scenario: An empirical study on the citizens' perception. Environmental Engineering and Management Journal, 18(10), pp. 2181-2192, 2019.

[22] Andretta, A., D'addato, F., Serrano-Bernardo, F., Zamorano, M. \& Bonoli, A., Environmental taxes to promote the EU circular economy's strategy: Spain vs. Italy. Environmental Engineering and Management Journal, 17(10), pp. 2307-2311, 2018. 
[23] Ragazzi, M., Fedrizzi, S., Rada, E.C., Ionescu, G., Ciudin, R. \& Cioca, L.I., Experiencing urban mining in an Italian municipality towards a circular economy vision. Energy Procedia, 119, pp. 192-200, 2017.

[24] Ministero dell'Ambiente e della Tutela del Territorio e del Mare in collaborazione con il Ministero dello Sviluppo Economico, Verso un modello di economia circolare per l'Italia Documento di inquadramento e di posizionamento strategico. https://circulareconomy.europa.eu/platform/sites/default/files/national_strategy_for_c ircular_economy_11_2017_it1.pdf. Accessed on: 23 Oct. 2020.

[25] Gazzetta Ufficiale della Repubblica Italiana, Law 4 October 2019, n. 117. https://www.gazzettaufficiale.it/eli/id/2019/10/18/19G00123/sg. Accessed on: 23 Oct. 2020.

[26] Circular Economy Network, Rapporto sull'economia circolare in Italia, Con focus sulla bioeconomia 2020. https://circulareconomynetwork.it/wp-content/uploads/2020/ 04/Rapporto-sulleconomia-circolare-in-Italia-2020_r04.pdf.

[27] Nikitina, B., Waste management and circular economy in the public discourse in Russia. Lecture Notes in Networks and Systems, 133, pp. 451-461, 2021.

[28] Rumyantseva, A., Rumyantseva, E., Berezyuk, M. \& Plastinina, J., Waste recycling as an aspect of the transition to a circular economy. IOP Conference Series: Earth and Environmental Science, 534(1), 012002, 2020.

[29] Nikitina, B.A., Circular and sharing economy practices and their implementation in Russian universities. Lecture Notes in Networks and Systems, 84, pp. 19-26, 2020.

[30] Ruohomaa, H. \& Ivanova, N., From solid waste management towards the circular economy and digital driven symbiosis. IOP Conference Series: Earth and Environmental Science, 337(1), 012032, 2019.

[31] Gitelman, L., Magaril, E., Kozhevnikov, M. \& Rada, E.C., Rational behavior of an enterprise in the energy market in a circular economy. Resources, 8(2),73, 2019.

[32] Fedotkina, O., Gorbashko, E. \& Vatolkina, N., Circular economy in Russia: Drivers and barriers for waste management development. Sustainability, 11(20), 5837, 2019.

[33] Kiselev, A., Magaril, E., Magaril, R., Panepito, D., Ravina, M. \& Zanetti, M.C., Towards circular economy: Evaluation of sewage sludge biogas solutions. Resources, 8(2), p. 91, 2019.

[34] International Finance Organization, Municipal solid waste management: Opportunities for Russia. https://www.ifc.org/wps/wcm/connect/06d5e7fc-5268-4142-a9bd31e4a050cdc9/PublicationRussiaRREP-SolidWasteMngmt-2012en.pdf?MOD=AJPERES\&CVID=jwzKQBD. Accessed on: 23 Oct. 2020.

[35] Federal Law No. 89-FZ On Production and Consumption Wastes. http://www.consultant.ru/document/cons_doc_LAW_19109.

[36] Federal Law No. 7-FZ On Environmental Protection. www.consultant.ru/document/ cons_doc_LAW_34823. Accessed on: 23 Oct. 2020.

[37] Ministry of Natural Resources and Environment Russian Federation, Moscow, State report on the state and protection of the environment of the Russian Federation in 2018, 2019. https://www.mnr.gov.ru/docs/o_sostoyanii_i_ob_okhrane_okruzhayushchey_ sredy_rossiyskoy_federatsii/gosudarstvennyy_doklad_o_sostoyanii_i_ob_okhrane_o kruzhayushchey_sredy_rossiyskoy_federatsii_v_2018_/. Accessed on: 19 Nov. $20 \overline{2} 0$.

[38] Industrial development strategies for the processing, treatment and disposal of industrial waste and MSW for the period up to 2030, Russian Government Order No 84-r. http://docs.cntd.ru/document/556353696. Accessed on: 19 Nov. 2020.

[39] Eurostat, Statistics explained. https://ec.europa.eu/eurostat/statistics-explained/ index.php/Main_Page. Accessed on: 23 Oct. 2020. 
[40] ISPRA, Rapporto Rifiuti Urbani, Edizione 2019. http://www.isprambiente.gov.it/files2019/pubblicazioni/rapporti/RapportoRifiutiUrba ni_VersioneIntegralen313_2019.pdf. Accessed on: 23 Oct. 2020.

[41] Romano, G., Ferreira, D.C., Marques, R.C. \& Carosi, L., Waste services' performance assessment: The case of Tuscany, Italy. Waste Management, 118, pp. 573-584, 2020.

[42] Calabrò, P.S. \& Pangallo, D., Analysis of the effect of separate collection on the composition of mixed municipal solid waste in Italy. Open Chemical Engineering Journal, 14, pp. 63-70, 2020.

[43] Di Foggia, G. \& Beccarello, M., Improving efficiency in the MSW collection and disposal service combining price cap and yardstick regulation: The Italian case. Waste Management, 79, pp. 223-231, 2018.

[44] Rada, E.C., Effects of MSW selective collection on waste-to-energy strategies. WIT Transactions on Ecology and the Environment, vol. 176, WIT Press: Southampton and Boston, pp. 215-223, 2013

[45] European Environment Agency, Bio-waste in Europe: Turning challenges into opportunities. https://www.eea.europa.eu/publications/bio-waste-in-europe. Accessed on: 23 Oct. 2020.

[46] Saldarriaga, J.F., Gallego, J.L. \& López, J.E., Determination of kinetics parameters for composting process of the organic fraction of municipal solid waste separated at source. Chemical Engineering Transactions, 70, pp. 217-222, 2018.

[47] Chatterjee, B. \& Mazumder, D., Anaerobic digestion for the stabilization of the organic fraction of municipal solid waste: A review. Environmental Reviews, 24(4), pp. 426459, 2016.

[48] Andreottola, G., Ragazzi, M., Foladori, P., Villa, R., Langone, M. \& Rada, E.C., The unit integrated approach for OFMSW treatment. UPB Scientific Bulletin, Series $C$, 74(1), pp. 19-26, 2012.

[49] Adami, L., Schiavon, M., Torretta, V., Costa, L. \& Rada, E.C., Evaluation of conventional and alternative anaerobic digestion technologies for applications to small and rural communities. Waste Management, 118, pp. 79-89, 2020.

[50] Zhang, D., Luo, W., Li, Y., Wang, G. \& Li, G., Performance of co-composting sewage sludge and organic fraction of municipal solid waste at different proportions. Bioresource Technology, 250, pp. 853-885, 2018.

[51] Tyagi, V.K., Fdez-Güelfo, L.A., Zhou, Y., Álvarez-Gallego, C.J., Garcia, L.I.R. \& Ng, W.J., Anaerobic co-digestion of organic fraction of municipal solid waste (OFMSW): Progress and challenges. Renewable and Sustainable Energy Reviews, 93, pp. 380399, 2018.

[52] Paillet, F., Barrau, C., Escudié, R. \& Trably, E., Inhibition by the ionic strength of hydrogen production from the organic fraction of municipal solid waste. International Journal of Hydrogen Energy, 45(10), pp. 5854-5863, 2020.

[53] Ali, A.H., Al-Mussawy, H.A., Ghazal, M.T. \& Hamadi, N.J., Experimental and theoretical study for hydrogen biogas production from municipal solid waste. Pollution, 5(1), pp. 147-159, 2019.

[54] Malinowski, M., Wolny-Koładka, K. \& Vaverková, M.D., Effect of biochar addition on the OFMSW composting process under real conditions. Waste Management, 84, pp. 364-372, 2019.

[55] Lucian, M., Volpe, M., Gao, L., Piro, G., Goldfarb, J.L. \& Fiori, L., Impact of hydrothermal carbonization conditions on the formation of hydrochars and secondary chars from the organic fraction of municipal solid waste. Fuel, 233, pp. 257-268, 2018. 
[56] Higher Institute for Environmental Protection and Research, Urban Waste Report Edition 2019. https://www.isprambiente.gov.it/it/archivio/eventi/2019/12/rapportorifiuti-urbani-edizione-2019. Accessed on: 23 Oct. 2020.

[57] Kozlov, G., Pushkarev, M., Danilovich, D. \& Garabadzhiu, A., Technologically significant properties of municipal solid waste compost. E3S Web of Conferences, $\mathbf{1 7 5}$, 12015, 2020.

[58] Mikhailova, N.V. \& Yasinskaya, A.V., Modern technologies for energy utilization of MSW. Ecology and Industry of Russia, 24(8), pp. 4-11, 2020.

[59] Semenova, G., Waste disposal, introduction of waste reform and environmental tax in Russia. E3S Web of Conferences, 138, 02012, 2019.

[60] Mikheeva, E., Katraeva, I., Moralova, E. \& Vorozhtsov, D., Utilization of the organic fraction of municipal solid wastes by solid-state anaerobic digestion with a pretreatment in a ferromagnetic particles vortex layer apparatus. International Multidisciplinary Scientific GeoConference Surveying Geology and Mining Ecology Management, SGEM, 19(5.1), pp. 793-799, 2019.

[61] Ministry of Energy of Moscow District, Press release about the construction renewable energy sources at "Torbeevo" landfill. https://minenergo.mosreg.ru/press/pressreleases/07-06-2020-18-28-55-bolee-30-000-tonn-uglekislogo-gaza-v-god-ot-poligo. Accessed on: 19 Nov. 2020.

[62] Verbeeck, K., De Vrieze, J., Biesemans, M. \& Rabaey, K., Membrane electrolysisassisted $\mathrm{CO}_{2}$ and $\mathrm{H}_{2} \mathrm{~S}$ extraction as innovative pretreatment method for biological biogas upgrading. Chemical Engineering Journal, 361, pp. 1479-1486, 2019.

[63] Wang, P., Qiao, Z., Li, X., Su, Y. \& Xie, B., Functional characteristic of microbial communities in large-scale biotreatment systems of food waste. Science of the Total Environment, 746, 141086, 2020.

[64] O'Connor, S., Ehimen, E., Pillai, S.C., Lyons, G. \& Bartlett, J., Economic and environmental analysis of small-scale anaerobic digestion plants on Irish dairy farms. Energies, 13(3), 637, 2020.

[65] Adami, L., Schiavon, M., Torretta, V., Costa, L. \& Rada, E.C., Evaluation of conventional and alternative anaerobic digestion technologies for applications to small and rural communities. Waste Management, 118, pp. 79-89, 2020.

[66] Vats, N., Khan, A.A. \& Ahmad, K., Options for enhanced anaerobic digestion of waste and biomass: A review. Journal of Biosystems Engineering, 45(1), pp. 1-15, 2020.

[67] Rabii, A., Aldin, S., Dahman, Y. \& Elbeshbishy, E., A review on anaerobic codigestion with a focus on the microbial populations and the effect of multi-stage digester configuration. Energies, 12(6), p. 1106, 2019.

[68] Siddique, M.N.I. \& Wahid, Z.A., Achievements and perspectives of anaerobic codigestion: A review. Journal of Cleaner Production, 194, pp. 359-371, 2018.

[69] Xie, S. et al., Anaerobic co-digestion: A critical review of mathematical modelling for performance optimization. Bioresource Technology, 222, pp. 498-512, 2016.

[70] Abad, V., Avila, R., Vicent, T. \& Font, X., Promoting circular economy in the surroundings of an organic fraction of municipal solid waste anaerobic digestion treatment plant: Biogas production impact and economic factors. Bioresource Technology, 283, pp. 10-17, 2019.

[71] Foladori, P. et al., SARS-CoV-2 from faeces to wastewater treatment: What do we know? A review. Science of the Total Environment, 743, 140444, 2020.

[72] Esposito, E., Dellamuzia, L., Ungo, M., Fuoco, A., Giorno L. \& Jansen, J.C., Simultaneous production of biomethane and food grade $\mathrm{CO}_{2}$ from biogas: An industrial case study. Energy and Environmental Science, 12(1), pp. 281-289, 2019. 